\title{
Rare crystalline nephropathy leading to acute graft dysfunction: a case report
}

\author{
Sahil Bagai ${ }^{1}$, Dinesh Khullar ${ }^{*}$ and Bhavna Bansal ${ }^{2}$
}

\begin{abstract}
Background: Adenine phosphoribosyl transferase (APRT) deficiency is a rare genetic form of kidney stones and/or kidney failure characterized by intratubular precipitation of 2,8 dihydroxyadenine crystals. Early diagnosis and prompt management can completely reverse the kidney injury.

Case presentation: 44 year old Indian male, renal transplant recipient got admitted with acute graft dysfunction. Graft biopsy showed light brown refractile intratubular crystals with surrounding giant cell reaction, consistent with APRT deficiency. Patient improved after receiving allopurinol and hydration.

Conclusion: APRT forms a reversible cause of crystalline nephropathy. High index of suspicion is required for the correct diagnosis as timely diagnosis has therapeutic implications.
\end{abstract}

Keywords: APRT, Crystalline nephropathy, Dihydroxyadenine

\section{Background}

Adenine phosphoribosyltransferase (APRT) deficiency is a rare autosomal recessive disease in the purine salvage pathway that causes excessive production of 2,8-dihydroxyadenine (DHA). APRT is an enzyme that converts adenine into adenosine monophosphate. Its deficiency results in the accumulation of adenine, which in turn gets converted to 2,8-dihydroxyadenine (DHA) by xanthine oxidase. DHA forms insoluble crystals in urine. Renal involvement occurs in isolation because DHA is not systemically deposited [1]. It manifests as nephrolithiasis or crystalline nephropathy in homozygous patients [2]. Diagnosis is suggested by either detection of urinary 2,8-DHA crystals or histologic findings of crystal nephropathy or kidney stone analysis. The disease should be confirmed by genetic testing or demonstration of absence to APRT activity in red blood cell lysate assay [3].

Most common cause of crystalline nephropathy seen in post transplant setting in developing world is primary hyperoxaluria which is a close mimicker of APRT deficiency. Inappropriate diagnosis can have serious therapeutic implications as former requires combined liver

\footnotetext{
* Correspondence: drdineshkhullar@gmail.com

${ }^{1}$ Department of Nephrology and Renal transplant medicine, Max

Superspeciality Hospital, 1 \& 2, Press Enclave Marg Saket, New Delhi, Delhi

110017, India

Full list of author information is available at the end of the article
}

kidney transplant and latter requires only medical management.

We report a case of renal transplant recipient who had no past history of nephrolithiasis but developed APRT related nephropathy in immediate post transplant period and successfully recovered after treatment.

\section{Case presentation}

44 year old Indian male was diagnosed as having chronic kidney disease in 2015, basic disease unknown, not evaluated in detail although he had family history of renal disease. He reached end stage renal disease status in December 2016 and was initiated on hemodialysis via a tunneled catheter and maintained on thrice/week dialysis. He underwent live donor renal allograft transplantation with wife as the donor in March 2017 at a private hospital, Delhi. He received Basiliximab as induction and was maintained on tacrolimus, mycophenolate mofetil (MMF) and steroids. His immediate post transplant period was uneventful apart from one episode of urinary tract infection which was managed with antibiotics. His serum creatinine was around $1.0-1.1 \mathrm{mg} / \mathrm{dl}$. Two months post transplantion he presented to our hospital with asymptomatic rise in serum creatinine to $2.0 \mathrm{mg} / \mathrm{dl}$. Patient denied any history of non compliance. Physical examination was essentially normal. Routine investigations showed hemoglobin $10.5 \mathrm{~g} / \mathrm{dl}$, total leucocyte count 
$5 * 10$ [3]/cumm and platelet count were 2.95*10 [4]/ cumm, urine routine showed protein $1+$, few RBC's and no pus cells. Urine protein creatinine ratio was 0.48 and tacrolimus level was $9.6 \mathrm{ng} / \mathrm{ml}$. Graft kidney doppler was normal. In view of unexplained acute graft dysfunction, graft biopsy was done which showed normal glomeruli with presence of multiple light brown annular intratubular crystals with surrounding giant cell reaction on light microscopy. These crystals were refractile under polarizing microscope. Immunofluorescence microscopy was negative. (Fig. 1 A, Fig. 1B and 2). Patient had no past history of nephrolithiasis but had a strong family history of nephrolithiasis. His maternal cousin and elder brother had died of kidney disease. He was worked up for primary hyperoxaluria in view of suspicion on kidney biopsy but normal plasma oxalate $\left(3.34 \mathrm{~g} / 1.73 \mathrm{~m}^{2} /\right.$ day $)$ and $24 \mathrm{~h}$ urinary oxalate levels $(55.56 \mathrm{mg})$ ruled out the possibility. To ascertain the cause genetic analysis was done which revealed a novel non sense varation in the exon 3 of the APRT gene that resulted in stop codon and premature truncation of the protein at codon $87 \mathrm{~s} / \mathrm{o} A P R T$ deficiency. The patient was advised good hydration and low purine diet and started on allopurinol $200 \mathrm{mg}$ daily. $\mathrm{He}$ attained a baseline serum creatinine within 1 month of therapy. His Uric acid level before initiation of therapy was $7 \mathrm{mg} / \mathrm{dl}$ and maintained between 5 and $6 \mathrm{mg} / \mathrm{dl}$ on therapy.

\section{Discussion and conclusion}

APRT deficiency is a rare inborn error of purine metabolism caused by mutation in the APRT gene. It is characterized by the presence of 2,8 DHA crystals which are radiolucent and are often confused with other xanthine crystals. Most cases of DHA accumulation in urine have been reported primarily from Japan, France, Unites states of America and Iceland. Four cases of APRT deficiency have been published from Indian subcontinent but none showed crystalline nephropathy in renal transplant recipient [4-6]. Nephrolithiasis and crystalline

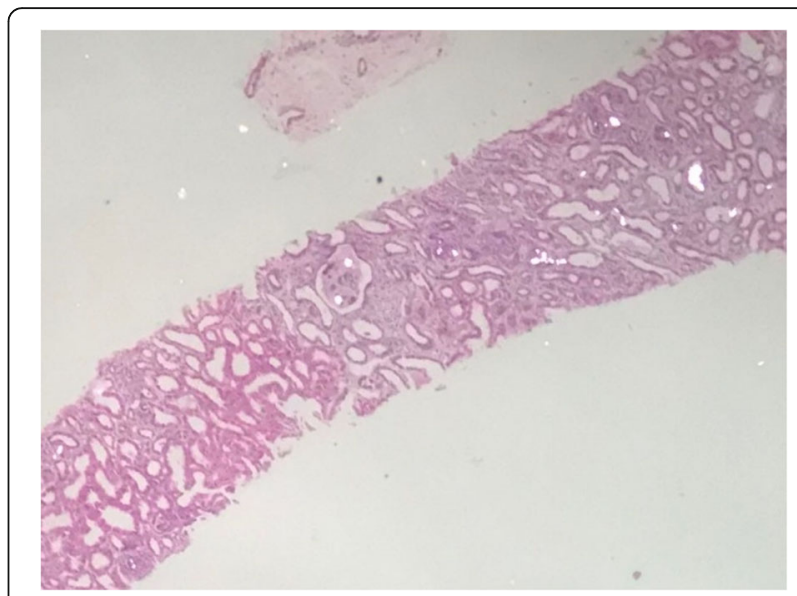

Fig. 2 Renal biopsy microphotograph showing multiple birefringent crystals under polarized light

nephropathy are two ways in which kidneys are affected [1]. Recurrent nephrolithiasis is a far more common presentation than crystalline nephropathy. It is usually misdiagnosed and mistreated as uric acid/xanthine stones as both are radiolucent stones and are not easily differentiated by stone analysis in patients presenting with nephrolithiasis [7]. Post renal transplantation, pathologists might mistake DHA disease as primary hyperoxaluria if they are not careful. The DHA crystals are brownish green as against oxalate crystals which are transparent. The APRT gene located on $16 \mathrm{q} 24$ is $2.6 \mathrm{~kb}$ long with five exons. Diagnosis is suggested by either detection of urinary 2,8-DHA crystals or histologic findings of crystal nephropathy or kidney stone analysis. The disease should be confirmed by genetic testing or demonstration of absence to APRT activity in RBC lysate [8]. APRT deficiency presents as Type I (complete deficiency in vivo and in vitro) and Type II (complete deficiency in vivo with $10-25 \%$ activity in vitro) [9].

In our patient we had suspected the disease entity keeping in mind the strong family history of renal

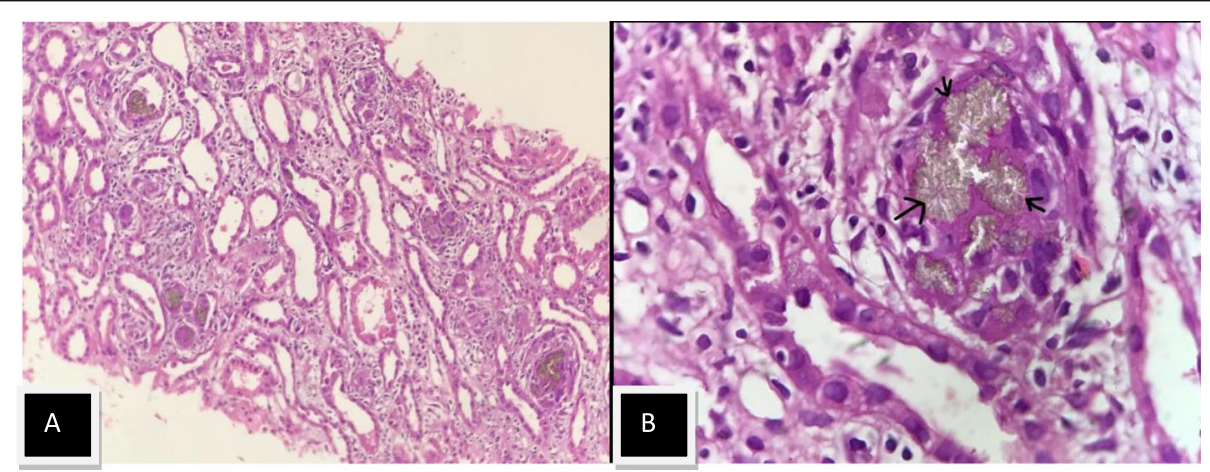

Fig. 1 Renal biopsy microphotograph showing multiple light brown intra tubular crystals with surrounding giant cell reaction. [PAS stain 10X(Fig. 1a) and 40x(Fig. 1b)] 
disease and by the presence of polarized intra tubular crystals on biopsy with normal plasma and urinary oxalate levels. Since APRT is a close mimicker, the final confirmation in our case was established with the help of genetic study which revealed a novel non sense mutation in exon 3.

Managing APRT deficient patients is rather straight forward. Xanthine oxidase inhibitor, low purine diet and good hydration form the pillars for management [10]. Time to diagnosis is the corner stone in case of crystalline nephropathy as late diagnosis would still lead to graft loss [11]. This is similar to a French study wherein only 1 patient out of 6 achieved good graft function despite correct diagnosis [12]. Fortunately our patient presented early and we could successfully manage him with good hydration, low purine diet and allopurinol.

Learning points from our case:

- Early recognition is critical as late diagnosis would lead to a progressive disease

- Intratubular crystallization on biopsy with negative work up for hyperoxaluria warrants a need for APRT evaluation.

- Life time xanthine oxidase inhibitor, low purine diet and high fluid intake forms the backbone of treatment in these patients.

- DHA crystals in urine or in biopsy are suggestive of APRT deficiency. However, confirmation is done with help of RBC enzyme assay or genetic testing.

\section{Abbreviations}

2,8-DHA: 2,8-dihydroxyadenine crystals; APRT: Adenine

phosphoribosyltransferase; MMF: Mycophenolate mofetil

\section{Acknowledgements}

No acknowledgement

\section{Authors' contributions}

SB wrote the case report. DK and BB corrected the report. SB did the biopsy and $B B$ read the biopsy. All authors read and approved the final manuscript.

\section{Funding}

No funding was obtained for this study.

\section{Availability of data and materials}

Not applicable

Ethics approval and consent to participate

Not applicable

\section{Consent for publication}

Written informed consent was obtained from the patient for publication of this case report. A copy of the written consent is available for review by the Editor of this journal.

\section{Competing interests}

The authors declare that they have no competing interests.

\section{Author details}

${ }^{1}$ Department of Nephrology and Renal transplant medicine, Max Superspeciality Hospital, 1 \& 2, Press Enclave Marg Saket, New Delhi, Delhi 110017, India. ${ }^{2}$ Department of Pathology, Max Superspeciality Hospital, 1 \& 2, Press Enclave Marg Saket, New Delhi, Delhi 110017, India.

Received: 5 August 2019 Accepted: 8 November 2019

Published online: 21 November 2019

\section{References}

1. Simmonds HA, Sahota AS, Van Acker KJ. Adenine phosphoribosyltransferase deficiency and 2,8-dihydroxyadenine lithiasis. In: Scriver CR, Beaudet AL, Sly WS, Valle D, editors. The metabolic and molecular bases of inherited diseases. 7th ed. New York, NY: McGraw-Hill; 1995. p. 2571-84.

2. Bollée G, Harambat J, Bensman A, et al. CJASN September. 2012:7(9):1521-7.

3. Kaartinen K, Hemmilä U, Salmela K, Räisänen-Sokolowski A, Kouri T, Mäkelä S. Adenine phosphoribosyltransferase deficiency as a rare cause of renal allograft dysfunction. J Am Soc Nephrol. 2014;25(4):671-4.

4. Sreejith P, Narasimhan KL. Sakuja V. 2,8 Dihydroxyadenine urolithiasis: a case report and review of literature. Indian J Nephrol. 2009 Jan;19(1):34-6.

5. Krishnappa P, Krishnamoorthy V, Gowda KK. Dihydroxyadenine stone with adénine phosphoribosyltransferase deficiency: a case report. Indian J Urol. 2017:33:246-8

6. Ceballos-Picot I, Saha A, Arora N, et al. Adenine Phosphoribosyltransferase deficiency due to novel mutation. Kidney Int Rep. 2018;4(4):624-8.

7. de Jong DJ, Assmann KJ, De Abreu RA, Monnens LA, van Liebergen FJ, Dijkman HB, Huysmans FT. 2,8-Dihydroxyadenine stone formation in a renal transplant recipient due to adenine phosphoribosyltransferase deficiency. J Urol. 1996;156:1754-5

8. Gopalakrishnan N, Rajashekhar D, Dhanapriya J, Dinesh Kumar T, Sakthirajan R, Balasubramaniyan T, Murugesan V. Unusual cause of crystalline nephropathy. Saudi J Kidney Dis Transpl. 2018;29:462-5.

9. Bollée G, Harambat J, Bensman A, Knebelmann B, Daudon M, Ceballos-Picot I. Adenine phosphoribosyltransferase deficiency. Clin J Am Soc Nephrol. 2012;7:1521-7.

10. Bollée G, Dollinger C, Boutaud L, Guillemot D, Bensman A, Harambat J, Deteix P, Daudon M, Knebelmann B, Ceballos-Picot I. Phenotype and genotype characterization of adenine phosphoribosyltransferase deficiency. J Am Soc Nephrol. 2010;21:679-88.

11. Edvardsson V, Palsson R, Olafsson I, et al. Clinical features and genotype of adenine phosphoribosyltransferase deficiency in Iceland. Am J Kidney Dis. 2001:38:473-80

12. Bertram A, Broecker V, Lehner F, Schwarz A. Kidney transplantation in a patient with severe adenine phosphoribosyl transferase deficiency: obstacles and pitfalls. Transpl Int. 2010;23:e56-8.

\section{Publisher's Note}

Springer Nature remains neutral with regard to jurisdictional claims in published maps and institutional affiliations.

Ready to submit your research? Choose BMC and benefit from:

- fast, convenient online submission

- thorough peer review by experienced researchers in your field

- rapid publication on acceptance

- support for research data, including large and complex data types

- gold Open Access which fosters wider collaboration and increased citations

- maximum visibility for your research: over $100 \mathrm{M}$ website views per year

At $\mathrm{BMC}$, research is always in progress.

Learn more biomedcentral.com/submissions 